\title{
Conceptual Design Development of a Fuel-Reforming System for Fuel Cells in Underwater Vehicles
}

\author{
Seung-Kyo Jung ${ }^{1}$, Won-Sim Cha ${ }^{1}$, Yeong-In Park ${ }^{1}$, Shin-Hyung Kim ${ }^{1}$ and Jungho Choi ${ }^{2, * \mathbb{D}}$ \\ 1 Naval \& Energy System R \& D, Daewoo Shipbuilding Marine Engineering, Gyeonggi-do 15011, Korea; \\ jungskyo@dsme.co.kr (S.-K.J.); cha032@dsme.co.kr (W.-S.C.); ijoai@dsme.co.kr (Y.-I.P.); \\ axiom@dsme.co.kr (S.-H.K.) \\ 2 Department of Naval Architecture and Offshore Engineering, Dong-A University, Busan 49315, Korea \\ * Correspondence: tamuchoi@dau.ac.kr
}

Received: 14 December 2019; Accepted: 13 April 2020; Published: 17 April 2020

\begin{abstract}
An air-independent propulsion system containing fuel cells is applied to improve the operational performance of underwater vehicles in an underwater environment. Fuel-reforming efficiently stores and supplies hydrogen required to operate fuel cells. In this study, the applicability of a fuel-reforming system using various fuels for underwater vehicles was analyzed by calculating the fuel and water consumptions, the amount of $\mathrm{CO}_{2}$ generated as a byproduct, and the amount of water required to dissolve the $\mathrm{CO}_{2}$ using aspen HYSYS (Aspen Technology, Inc., Bedford, MA, USA). In addition, the performance of the fuel-reforming system for methanol, which occupies the smallest volume in the system, was researched by analyzing performance indicators such as methanol conversion rate, hydrogen, yield and selectivity, and reforming efficiency under conditions at which pressure, temperature, steam-to-carbon ratio (SCR), and hydrogen separation efficiency vary. The highest reforming efficiency was $77.7-77.8 \%$ at $260{ }^{\circ} \mathrm{C}$ and $270{ }^{\circ} \mathrm{C}$. At SCR 1.5 , the reforming efficiency was the highest, which is $77.8 \%$, and the $\mathrm{CO}_{2}$ generation amount was the lowest at $1.46 \mathrm{kmol} / \mathrm{h}$. At high separation efficiency, the reforming efficiency increased due to the reduction of reactants, and a rate at which energy is consumed for endothermic reactions also decreased, resulting in a lower $\mathrm{CO}_{2}$ generation amount.
\end{abstract}

Keywords: underwater vehicle; fuel cell; fuel reforming; methanol; $\mathrm{CO}_{2}$

\section{Introduction}

Fuel cells generate electricity through the electrochemical reaction of oxygen and hydrogen. Hydrogen is separated into hydrogen ions and electrons at the anode, and the hydrogen ions move to the cathode and react with oxygen and electrons from the external circuit to generate water. The separated electrons move to the external circuit and form a current, thus generating electricity. Compared with the internal combustion engine, fuel cells are environment-friendly because they do not generate pollutants such as $\mathrm{CO}_{2}$, low noise because they do not have a driving unit, do not undertake explosions by combustion, and are highly efficient at electricity production by electrochemical reactions. Jen-Chieh Lee and Tony Shay [1] analyzed air-independent propulsion (AIP) systems containing fuel cells applied to underwater vehicles to enhance the underwater operational performance. P.C. Ghosh and U. Vasudeva [2] described the system configuration of conventional diesel-based electric submarines and a combination of fuel cell and battery. Conventional underwater vehicles using diesel engines and batteries can be easily exposed to enemies because their endurance is only a few days. However, underwater vehicles equipped with an AIP system containing fuel cells have an endurance of several days to several weeks. Psoma and Sattler [3] reported that Siemens developed a $120 \mathrm{~kW}$ polymer-electrolyte-membrane fuel cell (PEMFC) and the HDW (Howaldtswerke-Deutsche Werft) AG 
applied a $240 \mathrm{~kW}$ fuel cell system to a type 214. Maeda et al. [4] reported sea-going test results for Urashima, which is an autonomous underwater vehicle (AUV) using a fuel cell (4 kW). Mendez et al. [5] introduced a current fuel cell power system for an AUV and compared it with a battery power system. Kim [6] conceptually studied crewless underwater vehicle (UUV) with $1 \mathrm{~kW}$ polymer-electrolytic fuel cell. To supply hydrogen in an underwater environment, technologies to efficiently store hydrogen are required.

According to Ji et al. [7], the type 214 underwater weapon equipped with a fuel cell system, stores hydrogen in multiple metal hydride cylinders to supply to fuel cells. Metal hydride has an advantage of high hydrogen storage density per volume, but has limitations in increasing the endurance of the underwater vehicles due to the low deployment flexibility of metal alloy and long-term hydrogen charge. There are different methods to store hydrogen. Etienne Rivard et al. [8] presented a review of hydrogen storage systems relevant for mobility applications. Compressed, liquefied, cold/cryo compressed, carbon nanostructures, metal borohydrides, and Liquid Organic Hydrogen Carrier (LOHC), etc. have been known as the storage methods for hydrogen as shown in Table 1. Among them, compressed hydrogen and metal hydrides are adequate for underwater vehicle because the former is current industrial standard and the latter is higher volumetric energy density than the others. However, compression and a specific charging facility are necessary and safety requirements in terms of high pressure should be reinforced. To overcome these limitations and drawbacks, studies on the application of fuel-reforming technology are underway. The fuels used in fuel reforming are based on hydrocarbon and alcohol and have advantages of high hydrogen storage density per unit mass and volume and ability to store hydrogen as liquid at room temperatures. Reforming methods include steam reforming, partial oxidation reforming, and autothermal reforming. Purnima et al. [9] enhanced hydrogen production by adding a second autothermal ethanol reforming technology. Ahmed and Krumpelt [10] investigated a neutral point of autothermal reforming for various fuels and compared reforming technologies. The steam-reforming technology has a high hydrogen yield and technical maturity. Chiu et al. [11] examined methanol steam reforming in terms of the by-product region through thermodynamic analysis. Qimin Ming et al. [12] researched catalysts appropriate for a steam-reforming method for natural gas, isooctane, gasoline, and diesel fuels. Lutz et al. [13] analyzed steam reforming to produce hydrogen, based on thermodynamics. Meng Ni et al. [14] investigated catalysts for steam reforming and autothermal reforming of bio-ethanol. With the reforming technologies for different fuels, fuel processing for fuel cell systems in mobile applications has been studied. Doss et al. [15] studied the influence of varying the autothermal reformer (ATR) and system design and operating parameters on the performance of the fuel processors and fuel cell systems. Krumpel et al. [16] discussed various options for reforming hydrocarbon fuels suitable for transportation and portable power applications. Krummrich and Labres [17] developed a methanol reformer as a hydrogen supply system for next-generation fuel cell applications. Navantia in Spain built a S-80 equipped with an ethanol reformer.

Table 1. Storage methods overview.

\begin{tabular}{ccccc}
\hline Method & $\begin{array}{c}\text { Gravimetric Energy } \\
\text { Density (wt } \mathbf{~})\end{array}$ & $\begin{array}{c}\text { Volumetric Energy } \\
\text { Density (MJ/L) }\end{array}$ & $\begin{array}{c}\text { Temperature } \\
\text { (K) }\end{array}$ & $\begin{array}{c}\text { Pressure } \\
\text { (barg) }\end{array}$ \\
\hline Compressed & 5.7 & 4.9 & 293 & 700 \\
\hline Liquid & 7.5 & 6.4 & 20 & 0 \\
\hline Cold/Cryo Compressed & 5.4 & 4.0 & $40-80$ & 300 \\
\hline Carbon nanostructures & 2.0 & 5.0 & 298 & 100 \\
\hline Metal hydrides & 7.6 & 13.2 & 130 & 20 \\
\hline Metal borohydrides & $14.9-18.50$ & $9.8-17.6$ & 293 & 0 \\
\hline LOHC & 8.5 & 7 & 05 \\
\hline
\end{tabular}


In this study, the characteristics of steam reforming were evaluated through the 0-order model of aspen HYSYS for various fuels applicable to underwater vehicles in order to prepare basic data for evaluating the reforming performance of fuels for underwater vehicle fuel cells. In particular, the treatment of byproduct gases generated by fuel reforming such as $\mathrm{CO}_{2}$ was considered. In addition, the effects of variation of pressure, temperature, steam to carbon ratio (SCR), hydrogen separation efficiency on hydrogen yield and selectivity, reforming efficiency, $\mathrm{CO}_{2}$ generation amount, and water amount for dissolution of $\mathrm{CO}_{2}$ targeting fuels applicable to fuel cells were analyzed.

\section{Fuel-Reformer Modeling}

\subsection{Configuration and Condition of Fuel-Reformer Model}

In this study, the fuel-reformer model was simplified, as shown in Figure 1 to analyze the fuel-reforming performance of diesel, gasoline, ethanol, and methanol. For diesel and gasoline, which are multicomponent mixtures, hexadecane $\left(\mathrm{C}_{16} \mathrm{H}_{34}\right)$ and isooctane $\left(\mathrm{C}_{8} \mathrm{H}_{18}\right)$ were used, which are often used as substitute fuels $[18,19]$. For each fuel, the reformed gas containing hydrogen was generated through steam reforming, as shown in Equations (1)-(4). Then hydrogen is separated through a separator that can selectively separate hydrogen (e.g., palladium membrane), and high-purity hydrogen is supplied to the fuel cell after reducing pressure up to the fuel cell required pressure. The unseparated off-gas is fully burned with oxygen in a combustor and then cooled through a cooler, and the combustion heat supplies the heat required for reforming. Unlike fuel reforming on the land, underwater vehicles cannot use air in underwater operation and must use oxygen stored in the liquid state. In this study, however, the thermal energy required to vaporize oxygen in the liquid state for combustion was not included in the model.

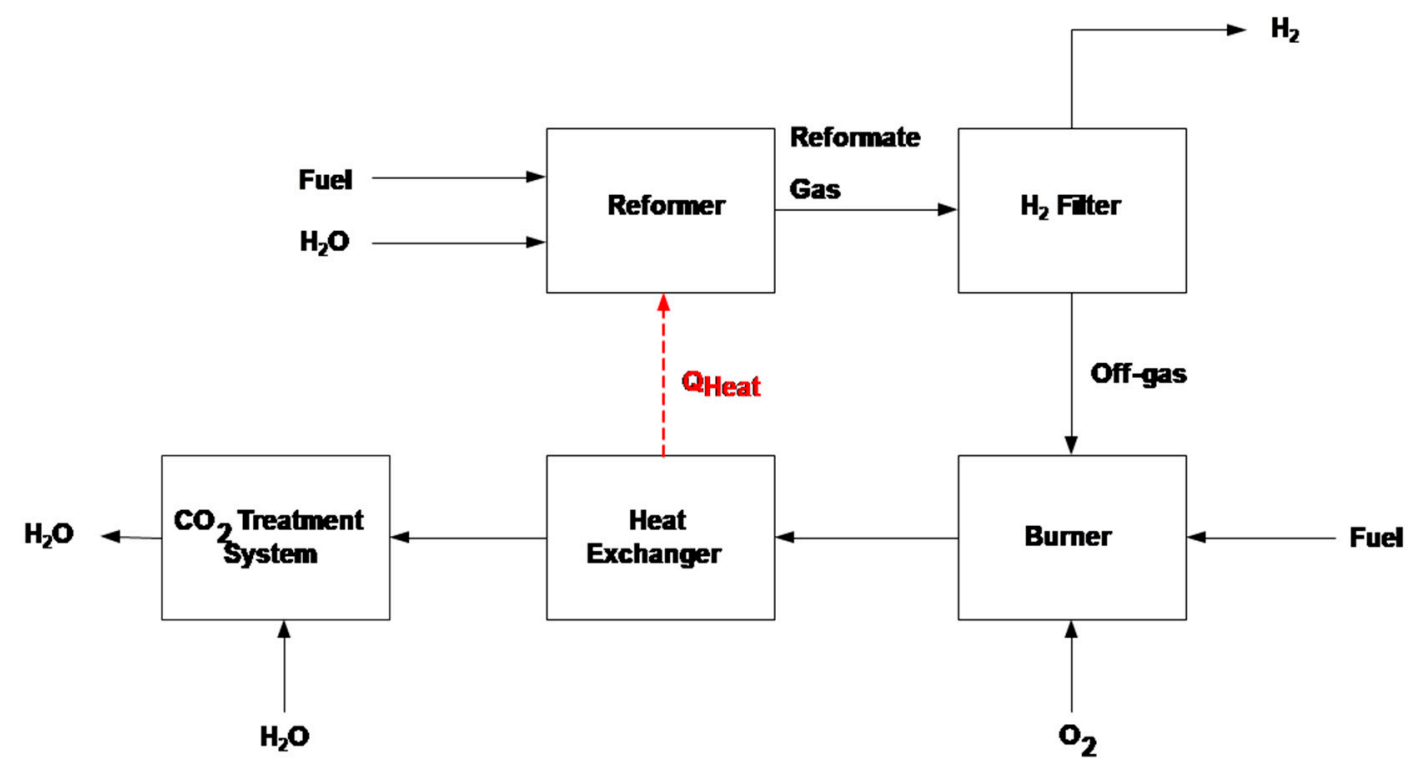

Figure 1. Block flow diagram for fuel reformer.

The fuel was supplied on the basis of generating hydrogen unit flow rate $(1 \mathrm{kmol} / \mathrm{h})$, and the flow rate of water was calculated by the assumption that SCR is 3 . The SCR here is defined in a water to fuel ratio as Equation (5).

$$
\begin{gathered}
\mathrm{C}_{16} \mathrm{H}_{34}+32 \mathrm{H}_{2} \mathrm{O} \rightarrow 49 \mathrm{H}_{2}+16 \mathrm{CO}_{2}, \Delta \mathrm{H}_{\mathrm{f}}=2336 \mathrm{~kJ} / \mathrm{mol}, \\
\mathrm{C}_{8} \mathrm{H}_{18}+16 \mathrm{H}_{2} \mathrm{O} \rightarrow 25 \mathrm{H}_{2}+8 \mathrm{CO}_{2}, \Delta \mathrm{H}_{\mathrm{f}}=1684 \mathrm{~kJ} / \mathrm{mol}, \\
\mathrm{C}_{2} \mathrm{H}_{5} \mathrm{OH}+3 \mathrm{H}_{2} \mathrm{O} \rightarrow 6 \mathrm{H}_{2}+2 \mathrm{CO}_{2}, \Delta \mathrm{H}_{\mathrm{f}}=173.4 \mathrm{~kJ} / \mathrm{mol},
\end{gathered}
$$




$$
\begin{gathered}
\mathrm{CH}_{3} \mathrm{OH}+\mathrm{H}_{2} \mathrm{O} \rightarrow 3 \mathrm{H}_{2}+\mathrm{CO}_{2}, \Delta \mathrm{H}_{\mathrm{f}}=49.4 \mathrm{~kJ} / \mathrm{mol}, \\
\mathrm{SCR}=\frac{\dot{\mathrm{n}}_{\mathrm{H}_{2} \mathrm{O}}}{\dot{\mathrm{n}}_{\text {Fuel, }}},
\end{gathered}
$$

Here, $\dot{\mathrm{n}}_{\mathrm{H}_{2} \mathrm{O}}$ is the mol number of water, and $\dot{\mathrm{n}}_{\mathrm{Fuel}, \mathrm{c}}$ is the mol number of the carbon contained in the fuel.

With respect to the supply conditions of the reactant, the temperature may follow the environmental condition underwater; however, for pressure, the underwater environment condition of the underwater vehicles must be considered. The high-purity hydrogen finally generated in fuel reforming is supplied to the fuel cell as fuel, and it generates electricity and water by reacting with oxygen. The generated water can be stored in the vehicles; however, the $\mathrm{CO}_{2}$ needs a large volume to store as gas; thus, it is efficient to discharge the $\mathrm{CO}_{2}$ out of the vehicles. If the $\mathrm{CO}_{2}$ is discharged with no treatment, it generates bubbles, which raises the likelihood of being detected by enemies. Thus, a technology to dissolve it in seawater is needed. Hence, to discharge $\mathrm{CO}_{2}$ efficiently by overcoming the water pressure at the water depth of the underwater vehicles, the pressure of the fuel reforming system must be maintained higher than the water pressure. Therefore, the supply pressure and temperature of the reactant were set at 25 bara and $25^{\circ} \mathrm{C}$, respectively, considering the operational depth of the underwater vehicles. For the reaction temperature, an appropriate temperature for the steam reforming reaction of each fuel was applied, as shown in Table 2.

Table 2. Temperature for reforming reaction.

\begin{tabular}{ccc}
\hline Fuel & Chemical Formula & Reaction Temperature \\
\hline Diesel & $\mathrm{C}_{16} \mathrm{H}_{34}$ & $800{ }^{\circ} \mathrm{C}$ \\
Gasoline & $\mathrm{C}_{8} \mathrm{H}_{18}$ & $800{ }^{\circ} \mathrm{C}$ \\
Ethanol & $\mathrm{C}_{2} \mathrm{H}_{5} \mathrm{OH}$ & $800^{\circ} \mathrm{C}$ \\
Methanol & $\mathrm{CH}_{3} \mathrm{OH}$ & $300^{\circ} \mathrm{C}$ \\
\hline
\end{tabular}

For the separator, a dense metal membrane (e.g., palladium membrane) that has a small volume was adopted because hydrogen purifiers such as pressure swing adsorption (PSA) are inappropriate considering placement in the limited space of the vehicles. Palladium is a representative metal that can selectively separate hydrogen in a gas containing hydrogen and impurities. However, the separation performance can be reduced when hydrogen is separated at temperatures below $300{ }^{\circ} \mathrm{C}$ due to damage of the metal grids of palladium. Therefore, the temperature of the reformed gas supplied to the separator was set at $350^{\circ} \mathrm{C}$, and the separation efficiency, which is indicated by the ratio of the separated hydrogen and supplied hydrogen, was assumed to be $85 \%[20,21]$.

The high-temperature combustion gas generated by the combustion reaction of the off-gas is cooled up to $350{ }^{\circ} \mathrm{C}$ through the heat exchanger. The thermal energy is used as the reaction energy required for fuel reforming. When the thermal energy was lower than the reaction energy, the energy balance was satisfied by burning additional fuel. However, in the case of methanol, whose reaction temperature is lower than $350^{\circ} \mathrm{C}$, additional fuel was supplied to heat the reformate gas by $350{ }^{\circ} \mathrm{C}$. The oxygen amount required for the combustion reaction of each fuel was calculated using Equations (6)-(10).

$$
\begin{aligned}
2 \mathrm{C}_{16} \mathrm{H}_{34}+49 \mathrm{O}_{2} & \rightarrow 34 \mathrm{H}_{2} \mathrm{O}+32 \mathrm{CO}_{2} \\
2 \mathrm{C}_{8} \mathrm{H}_{18}+25 \mathrm{O}_{2} & \rightarrow 18 \mathrm{H}_{2} \mathrm{O}+16 \mathrm{CO}_{2} \\
\mathrm{C}_{2} \mathrm{H}_{5} \mathrm{OH}+3 \mathrm{O}_{2} & \rightarrow 3 \mathrm{H}_{2} \mathrm{O}+2 \mathrm{CO}_{2} \\
2 \mathrm{CH}_{3} \mathrm{OH}+3 \mathrm{O}_{2} & \rightarrow 4 \mathrm{H}_{2} \mathrm{O}+2 \mathrm{CO}_{2} \\
2 \mathrm{CO}+\mathrm{O}_{2} & \rightarrow 2 \mathrm{CO}_{2}
\end{aligned}
$$




\subsection{Fuel-Reformer Modeling}

To analyze the fuel reforming performance, the process model was designed using the material database and equipment library provided by aspen HYSYS, as shown in Figure 2. For the thermodynamic model of materials, the Peng Robinson state equation, which is appropriate for hydrocarbon and hydrogen gases, was applied.

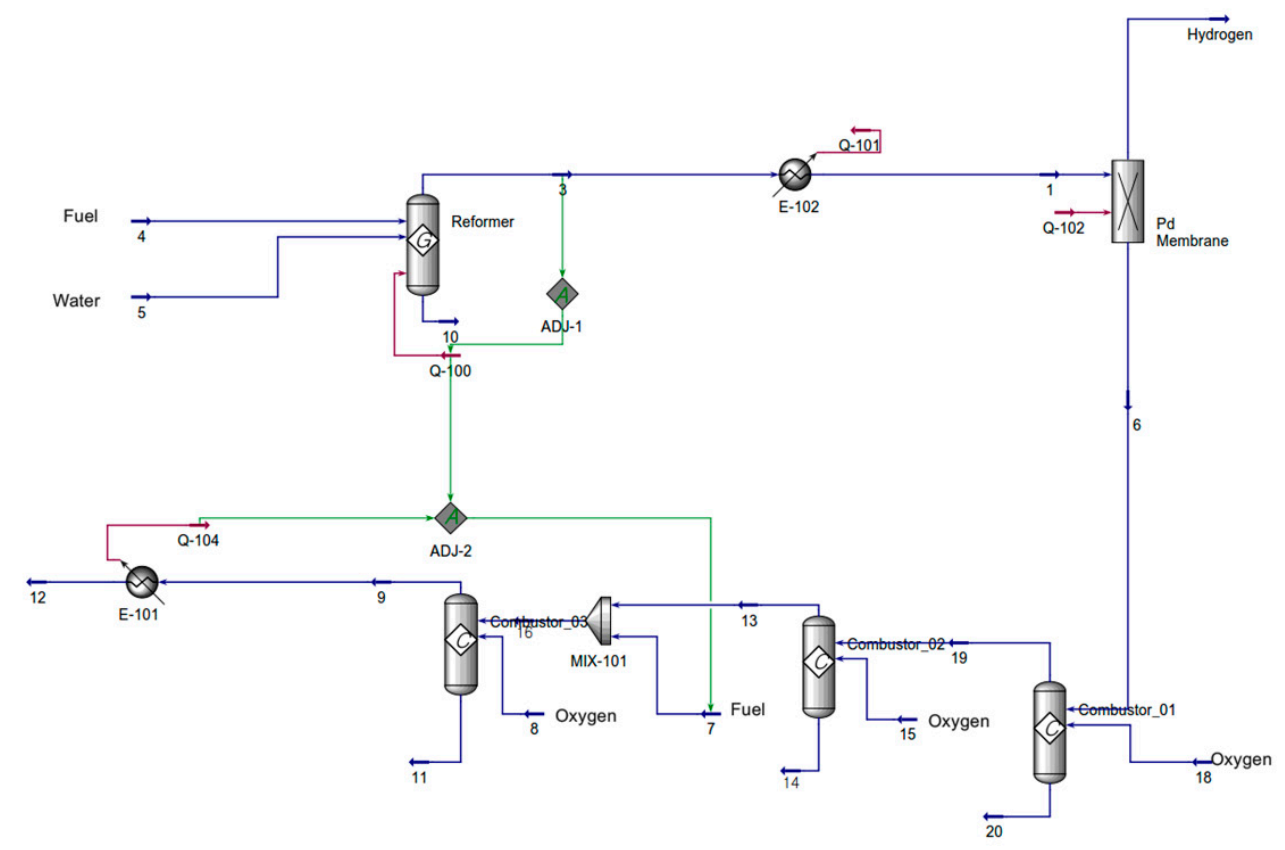

Figure 2. Fuel-reformer modeling.

For the fuel reformer, a Gibbs reactor, which calculates the reaction equilibrium that minimizes the Gibbs energy, was applied. This reactor model is appropriate for comparing performance based on thermodynamic theory when the materials of the reactant and product are known through the steam-reforming reaction formula of each fuel. The heater/cooler (E-102) after the reformer reduces the temperature of reformed gas to the required temperature of $\mathrm{Pd}$ membrane filter.

Palladium is a representative metal that can selectively separate hydrogen in a gas containing hydrogen and impurities and makes hydrogen with purity over $99.999 \%$ [22]. The separator was modeled to enable the separation of high-purity hydrogen with a component splitter, which can extract only the desired material among the supplied materials, and by reflecting the separation efficiency.

For the combustor, a conversion reactor was applied so that only $\mathrm{CO}_{2}$ was included in the exhaust gas by fully burning the unseparated hydrogen and impure gases. Because only one reaction formula can be input to one conversion reactor, three reactors were arranged in a series to include combustion reactions corresponding to hydrogen, carbon monoxide, and additional fuel. The flow rate of the additional fuel was calculated to supply the energy required to heat reactants to the steam-reforming reaction temperature of each fuel. In the case of methanol, however, which requires energy for additional heat because its reaction temperature is $50^{\circ} \mathrm{C}$ lower than the operating temperature of the palladium membrane, the fuel amount was calculated by considering the additional heat together with the reforming reaction heat, unlike other fuels.

The $\mathrm{CO}_{2}$ generated by fuel reforming and combustion must be discharged out of the vehicles after dissolving it by contact with seawater. Andrew Dickson [23] researched a method for measuring the chemical equilibrium of seawater and $\mathrm{CO}_{2}$ and the $\mathrm{CO}_{2}$ dissolution amount. However, since the present study is a conceptual stage study, the seawater was substituted with pure water, and the amount of water required for $\mathrm{CO}_{2}$ dissolution was calculated. The model proposed by Duan and 
Sun [24], which can calculate the $\mathrm{CO}_{2}$ dissolution amount for pure water and $\mathrm{NaCl}$ solution under the conditions of $273-533 \mathrm{~K}$ and $0-2000$ bar was used in this study.

\section{Results and Discussion}

\subsection{Fuel-Reformer Modeling}

Underwater vehicles have very limited space for installing equipment. Therefore, a fuel with a high energy density must be selected to supply hydrogen to fuel cells by applying fuel reforming to vehicles. In this study, the volume required for storing reactants and byproduct processing per unit of hydrogen production through steam reforming was analyzed for diesel, gasoline, ethanol, and methanol, which are applicable to underwater vehicles.

Because steam reforming is an endothermic reaction, fuel, water, and thermal energy to maintain reaction temperature must be supplied. Figure 3 shows a graph indicating the amount of fuel, water as reactants and oxygen used in combustion for thermal energy supply required for producing $1 \mathrm{kmol} / \mathrm{h}$ of hydrogen in steam reforming of each fuel. Diesel and gasoline consume less fuel because the mol number of the generated hydrogen is higher than those of other fuels; however, it requires a large amount of water due to many carbons in the fuel, and a large amount of oxygen gas is consumed to maintain the high reaction temperature. In the case of ethanol, a large amount of fuel is consumed due to the low mol number of hydrogen generated through reforming, and the amount of water required for reforming also increased as a result. In the case of methanol, the amount of fuel required for reforming is large compared to other fuels, but it consumes the smallest amount of reactants in general. In brief, to produce $1 \mathrm{kmol}$ of hydrogen, $47.6,51.7,53.5$, and $46.3 \mathrm{~kg}$ of reactants and oxygen, which is an oxidant, are consumed for diesel, gasoline, ethanol, and methanol, respectively.

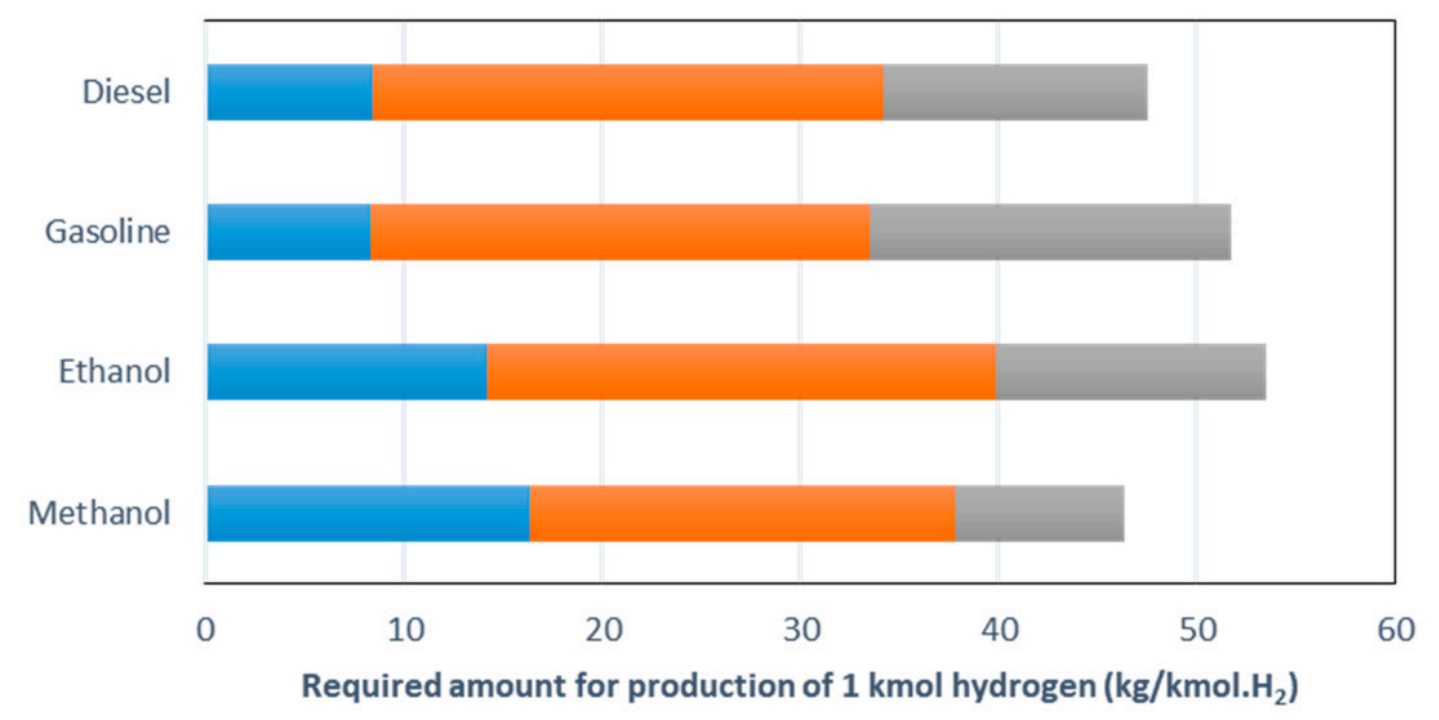

a Fuel $=$ Water $=\mathrm{O}_{2}$

Figure 3. Reactants consumption per produced $\mathrm{H}_{2}$ of $1 \mathrm{kmol}$ for diesel, gasoline, ethanol, and methanol.

Figure 4 shows the heating value required for a steam-reforming reaction for each fuel and the fuel flow rate that must be additionally supplied. Methanol requires a lower heating value than other fuels, but it could be inferred that a more substantial amount of fuel is consumed due to the lowest heating value of methanol, as shown in Table 3. 


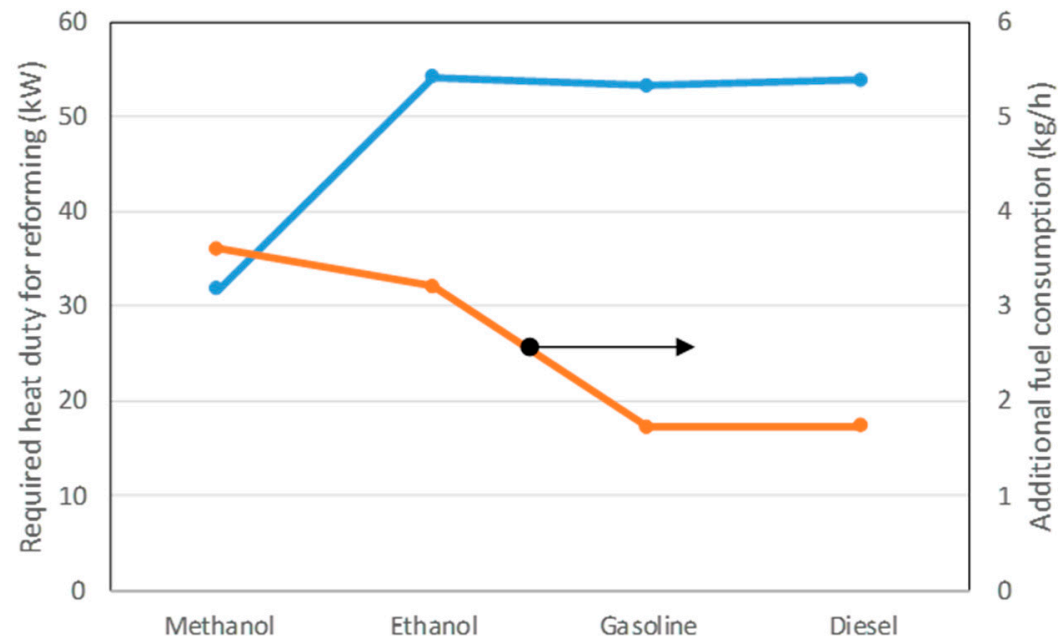

Figure 4. Required heat duty for steam reforming and additional fuel amount per produced $\mathrm{H}_{2}(1 \mathrm{kmol})$ for diesel, gasoline, ethanol, and methanol.

Table 3. Fuel LHV (lower heating value, Std. condition).

\begin{tabular}{cc}
\hline Fuel & LHV \\
\hline Diesel & $1.004 \times 10^{7} \mathrm{~kJ} / \mathrm{kmol}$ \\
Gasoline & $5.119 \times 10^{6} \mathrm{~kJ} / \mathrm{kmol}$ \\
Ethanol & $1.235 \times 10^{6} \mathrm{~kJ} / \mathrm{kmol}$ \\
Methanol & $6.381 \times 10^{5} \mathrm{~kJ} / \mathrm{kmol}$ \\
\hline
\end{tabular}

Figure 5 shows the amount of $\mathrm{CO}_{2}$ generated per $1 \mathrm{kmol}$ of hydrogen and the amount of water required to dissolve $\mathrm{CO}_{2}$. If the $\mathrm{CO}_{2}$ generation amount is large, the amount of water to process it also increases. Therefore, the design should minimize the $\mathrm{CO}_{2}$ generation for application to underwater vehicles. Methanol has a larger supply amount than other fuels but has a small mol number of the generated $\mathrm{CO}_{2}$ per $1 \mathrm{~mol}$ of fuel. Thus, the $\mathrm{CO}_{2}$ generation amount is the smallest, and the amount of water for dissolution can be minimized as well.

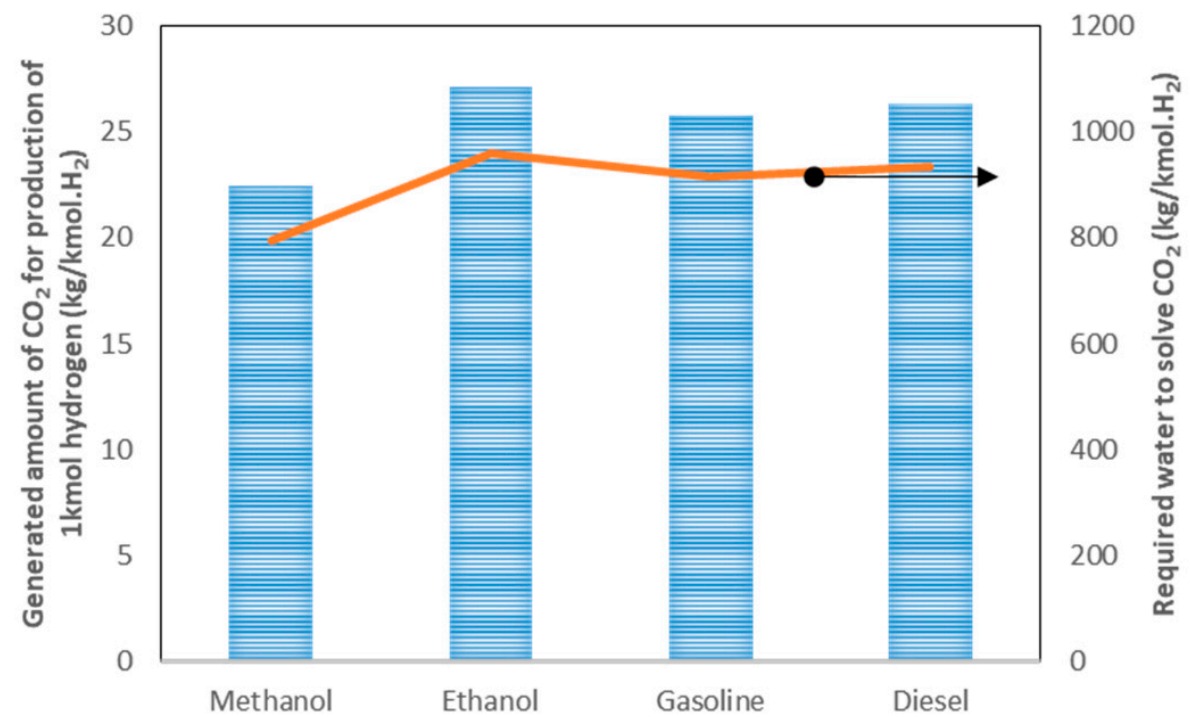

Figure 5. $\mathrm{CO}_{2}$ to be generated and required water to solve $\mathrm{CO}_{2}$ per produced $\mathrm{H}_{2}(1 \mathrm{kmol})$ for diesel, gasoline, ethanol, and methanol. 
The underwater vehicle design must consider not only the weight of equipment and fuels but also their volumes. Therefore, the volumes of the fuel, oxygen, and water required for fuel reforming, and the volume of the compensation water for which the weight should be compensated when $\mathrm{CO}_{2}$ is discharged out of the vehicles must be analyzed. As shown in Figure 6, the volume of the fuel, water, oxygen consumed for steam reforming of each fuel, and the compensation water for the discharge of $\mathrm{CO}_{2}$ was distinguished from fuels. In the case of diesel and gasoline, the required spaces are almost the same, and ethanol appears to occupy the largest volume. Methanol has a large fuel storage space because the consumption amount is larger than those of other fuels, but it occupied the smallest volume because the space for compensation water of oxygen and $\mathrm{CO}_{2}$ is small.

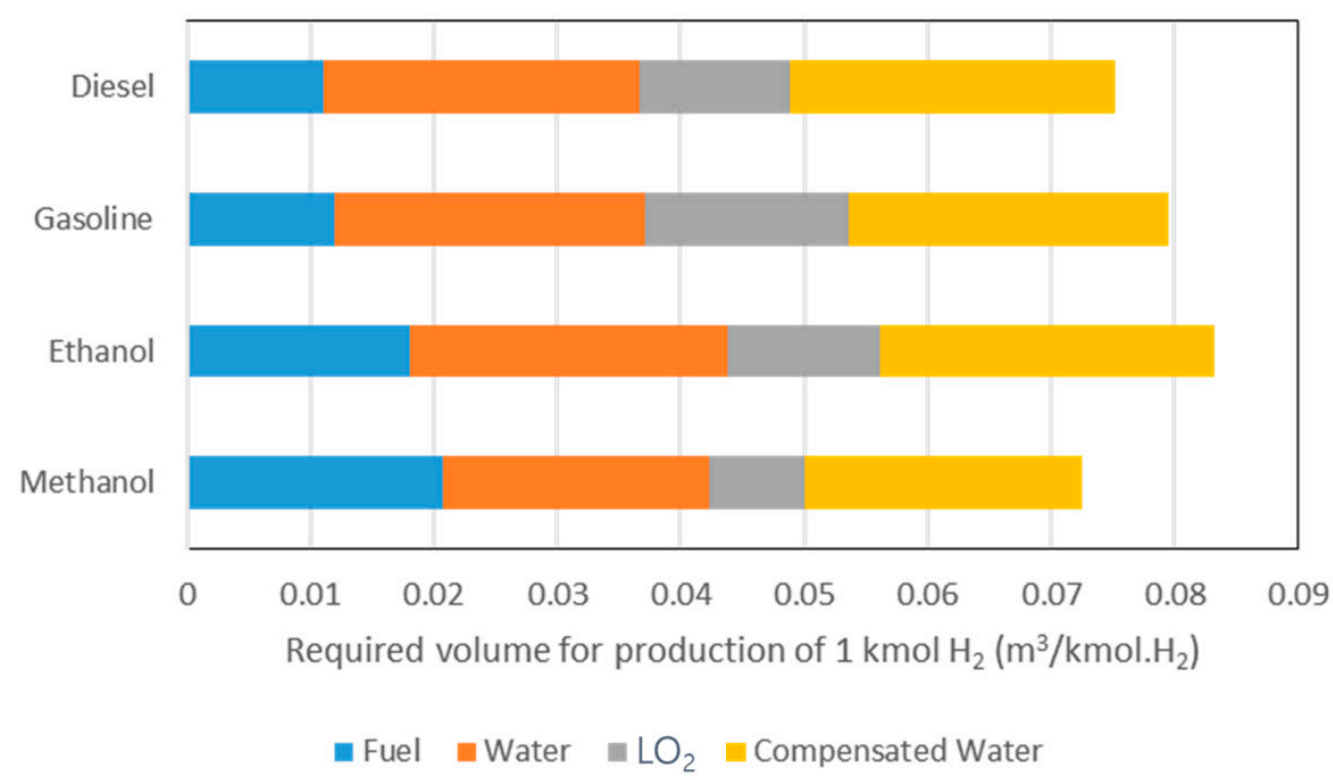

Figure 6. Required volume per produced $\mathrm{H}_{2}(1 \mathrm{kmol})$ for diesel, gasoline, ethanol, and methanol.

\subsection{Methanol Steam-Reforming Performance Analysis}

To analyze the performance according to the changed operation conditions of steam reforming for methanol which is considered to be applicable to underwater vehicles, the effects of reforming pressure and temperature, SCR, and the separation efficiency variation were analyzed.

The flow rate of hydrogen produced by methanol steam reforming was calculated based on $120 \mathrm{~kW}$ PEMFC. A fuel cell consumes hydrogen with various velocities according to power and reaction. Power and reaction are expressed as in Equations (11)-(14).

$$
\begin{gathered}
\mathrm{P}=\mathrm{VI}, \\
\text { Anode }: \mathrm{H}_{2} \rightarrow 2 \mathrm{H}^{+}+2 \mathrm{e}^{-}, \\
\text {Cathode }: 2 \mathrm{H}^{+}+\frac{1}{2} \mathrm{O}_{2}+2 \mathrm{e}^{-} \rightarrow \mathrm{H}_{2} \mathrm{O}, \\
\text { Total }: \mathrm{H}_{2}+\frac{1}{2} \mathrm{O}_{2} \rightarrow \mathrm{H}_{2} \mathrm{O},
\end{gathered}
$$

Hydrogen consumption is calculated by Equation (15) through the above stoichiometric coefficient of hydrogen and electrons [25]. The current was obtained by assuming that the single cell voltage is $0.7 \mathrm{~V}$; actually it is a function of the load and the operating point for the PEMFC is typically in the range of $0.5-0.9 \mathrm{~V}[26]$, thereby the fuel cell needs hydrogen of $3.2 \mathrm{kmol} / \mathrm{h}$.

$$
\mathrm{H}_{2}=-\frac{\mathrm{I}}{\mathrm{nF}}(\mathrm{mol} / \mathrm{s}),
$$


Figure 7 shows the trends of the methanol conversion ratio, hydrogen yield and selectivity, reforming efficiency, and $\mathrm{CO}_{2}$ discharge flow rate when the reaction pressure was changed to 1.013, 5, 10,20 , and 30 bara at $1.5 \mathrm{SCR}$ and a reaction temperature of $300^{\circ} \mathrm{C}$. Here, methanol conversion ratio, hydrogen yield, hydrogen selectivity, and reforming efficiency are expressed as Equations (16)-(19).

$$
\begin{gathered}
\mathrm{X}_{\mathrm{MeOH}}=\frac{\mathrm{MeOH}^{\text {feed }}-\mathrm{MeOH}^{\text {out }}}{\mathrm{MeOH}^{\text {feed }}}, \\
\mathrm{Y}_{\mathrm{H}_{2}}=\frac{\mathrm{H}_{2}{ }^{\text {out }}}{3 \mathrm{MeOH}^{\text {feed }}}, \\
\mathrm{S}_{\mathrm{H}_{2}}=\frac{\mathrm{Y}_{\mathrm{H}_{2}}}{\mathrm{X}_{\mathrm{MeoH}}}, \\
\eta_{\text {ref }}=\frac{\mathrm{LHV}\left(\mathrm{H}_{2}\right)^{\text {out }}}{\mathrm{LHV}\left(\mathrm{MeOH}^{\text {feed }}+\mathrm{MeOH}^{\text {com }}\right)},
\end{gathered}
$$
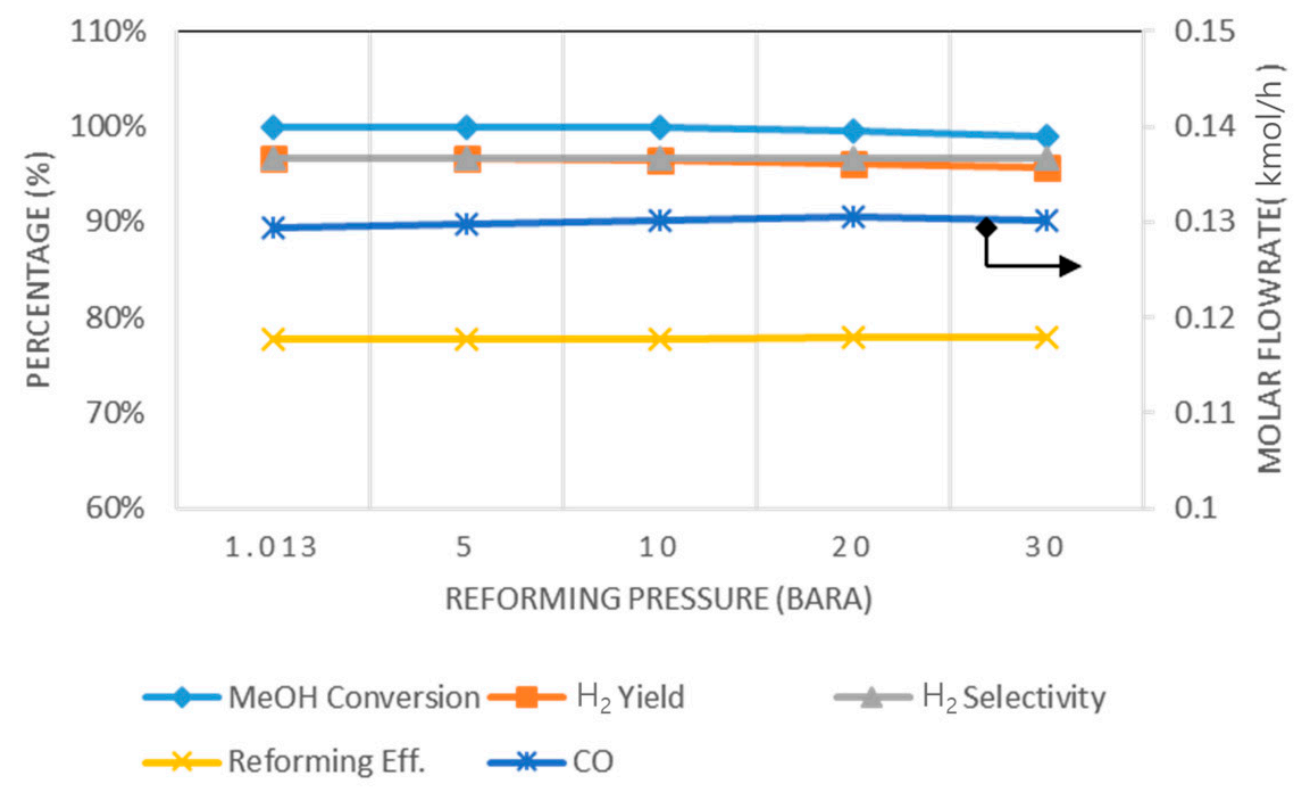

$-\mathrm{H}_{2}$ Selectivity

Figure 7. Effect of reforming pressure on $\mathrm{MeOH}$ conversion, $\mathrm{H}_{2}$ yield, $\mathrm{H}_{2}$ selectivity, reforming efficiency and $\mathrm{CO}$ flow rate.

In the above equations, $\mathrm{MeOH}^{\text {feed }}$ and $\mathrm{MeOH}^{\text {out }}$ are the amount of methanol supplied to the reactor and the methanol remaining after reaction. $\mathrm{H}_{2}$ out is the high-purity hydrogen separated from the separator. Furthermore, $\mathrm{MeOH}^{\mathrm{com}}$ is the additional fuel supplied to the combustor. The lower heating value (LHV) of hydrogen and methanol are $240.4 \mathrm{~kJ} / \mathrm{mol}$ and $675.99 \mathrm{~kJ} / \mathrm{mol}$, respectively.

As the pressure increased, the methanol conversion ratio and hydrogen yield showed a decreasing tendency. For the methanol steam-reforming reaction, the mol number of the product is higher than that of the reactant, as shown in Equation (4). Thus, when the pressure increases, the reaction equilibrium is reached in the direction of decreasing pressure, that is, by reverse reaction as in Le Chatelier's law. The reforming efficiency was insensitive to pressure change, and the generation of $\mathrm{CO}_{2}$ decreased with rising pressure, as shown in Figure 8. This is due to a thermodynamically theoretical reaction and high pressure combustion features. As the reaction pressure increases, CO increases between 1.013 bara and 20 bara, and shows a downward trend from 20 bara to 30 bara as shown in Figure 7. 


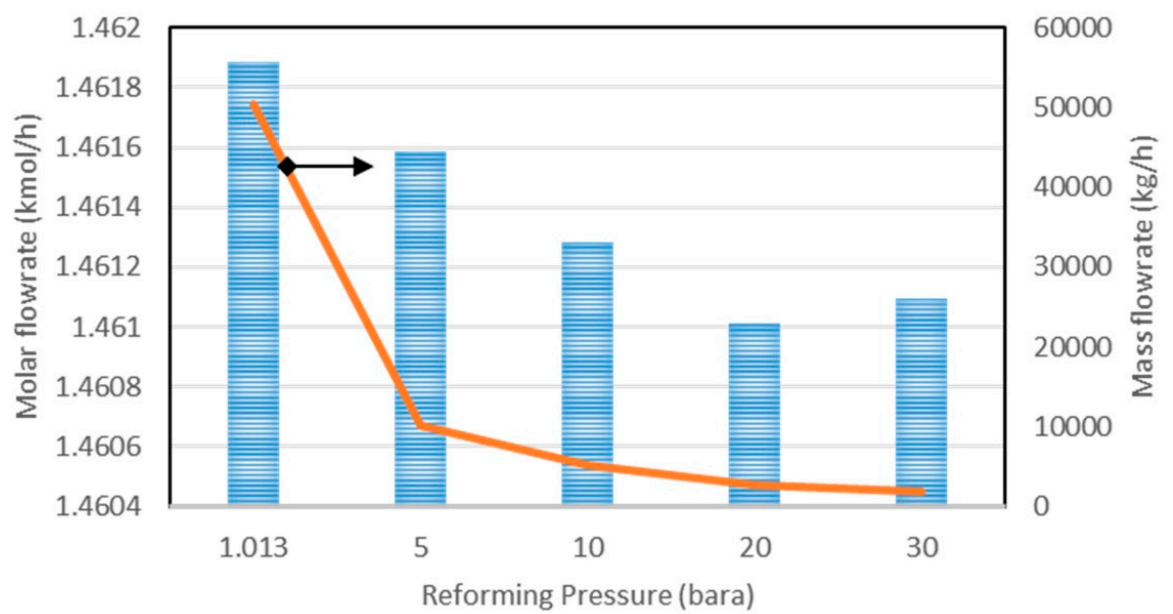

$\equiv \mathrm{CO}_{2}$ (Exhaust Gas) —Water for $\mathrm{CO}_{2}$ Treatment

Figure 8. Effect of reforming pressure on $\mathrm{CO}_{2}$ generated and water to solve $\mathrm{CO}_{2}$.

Thus, additional methanol amount was reduced because $\mathrm{CO}$ was combusted and utilized as thermal energy through combustion. The proportional relation of pressure and temperature in the gas equation of the combustion gas, so a higher temperature is generated at a higher pressure, and more thermal energy can be recovered. Therefore, the fuel amount decreases with rising pressure, and the $\mathrm{CO}_{2}$ generation amount is also reduced.

The equilibrium constant of the reaction is a function of temperature; thus, the reaction is most sensitive to temperature variation. Figure 9 shows the impact of reaction temperature variation on major analysis factors at $1.5 \mathrm{SCR}$ and a reaction pressure of 25 bara. With rising reaction temperature, the methanol conversion ratio increases, but the hydrogen selectivity decreases. The reforming efficiency was the highest at $77.7 \%-77.8 \%$ at $260{ }^{\circ} \mathrm{C}$ and $270{ }^{\circ} \mathrm{C}$. The increasing trend of $\mathrm{CO}$ generation amount suggests that the hydrogen generation amount decreases, and $\mathrm{CO}$ increases at high reaction temperatures. Figure 10 shows that at the reaction temperature of $250^{\circ} \mathrm{C}$ and a reaction pressure of $25 \mathrm{bara}$, the $\mathrm{CO}_{2}$ generation amount is $1.69 \mathrm{kmol} / \mathrm{h}$, and it sharply decreased to $1.46 \mathrm{kmol} / \mathrm{h}$ at $260{ }^{\circ} \mathrm{C}$ and then slowly decreased to $300{ }^{\circ} \mathrm{C}(1.39 \mathrm{kmol} / \mathrm{h})$. This is because as the temperature increased, the fuel amount decreased due to the increase in the amount of combustion by $\mathrm{CO}$.
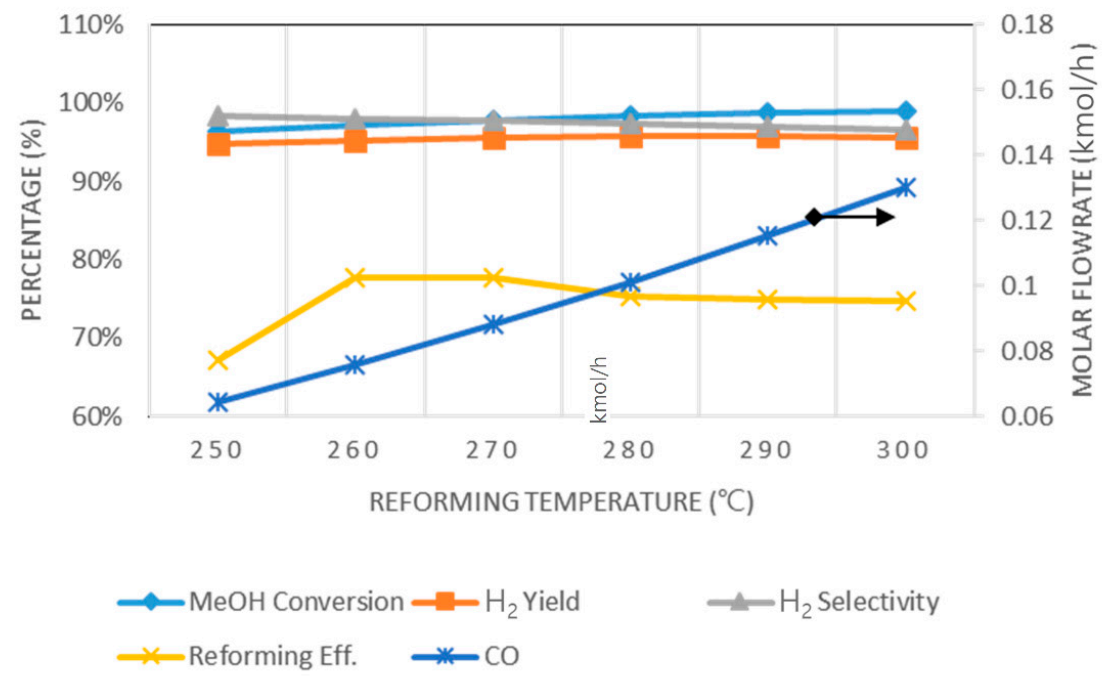

$-\mathrm{H}_{2}$ Selectivity

Figure 9. Effect of reforming temperature on $\mathrm{MeOH}$ conversion, $\mathrm{H}_{2}$ yield, $\mathrm{H}_{2}$ selectivity, reforming efficiency and $\mathrm{CO}$ flow rate. 


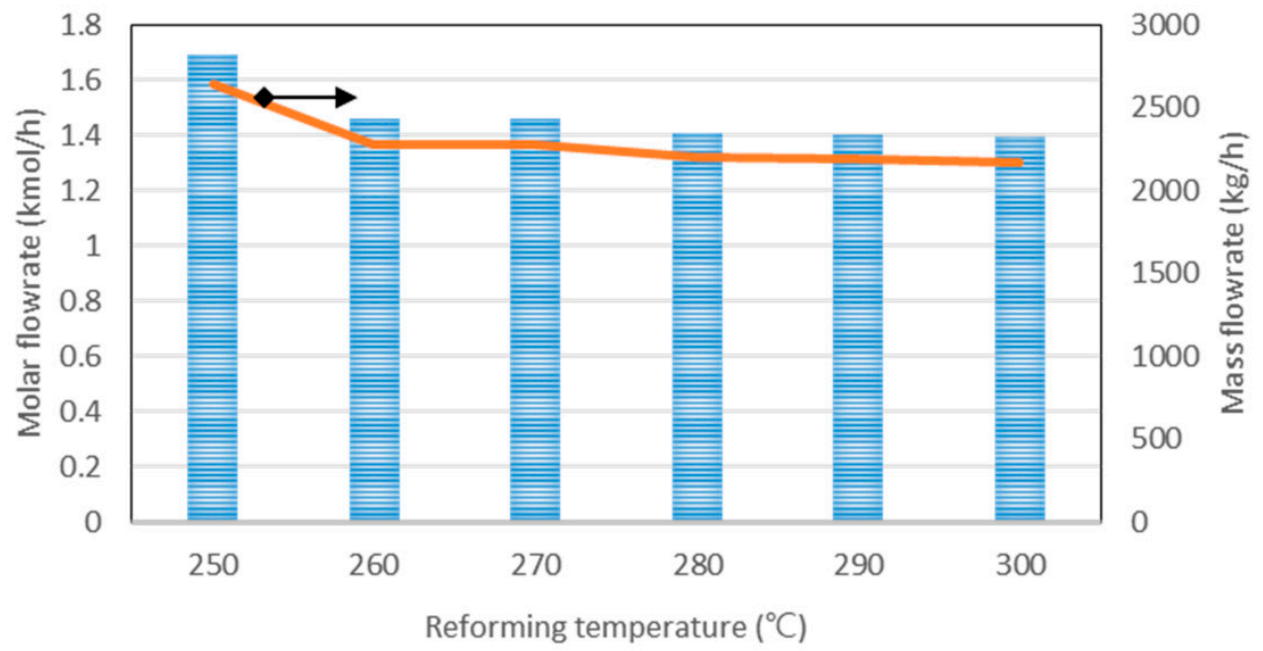

$\equiv \mathrm{CO}_{2}$ (Exhaust Gas) $\quad$ Water for $\mathrm{CO}_{2}$ Treatment

Figure 10. Effect of reforming temperature on $\mathrm{CO}_{2}$ generated and water to solve $\mathrm{CO}_{2}$.

At the reaction temperature of $300^{\circ} \mathrm{C}$ and the reaction pressure of $25 \mathrm{bara}$, when the SCR increased from 1 to 3 , the methanol conversion ratio, hydrogen yield and selectivity increased, but the reforming efficiency increased between SCR 1 and 1.5 and decreased from SCR 1.5 as shown in Figure 11. This is because as the SCR increases, the heating value for heating and vaporizing water also increases, and the additional fuel amount becomes higher as a result. An increase of SCR has the advantage of a high hydrogen generation amount, but it increases the additional fuel amount and the water storage amount. Therefore, it cannot be considered an advantage of the underwater vehicles design perspective. At SCR 1.5, the reforming efficiency was the highest at $77.8 \%$, and the $\mathrm{CO}_{2}$ generation amount was the lowest at $1.46 \mathrm{kmol} / \mathrm{h}$. From above SCR 1.5, the amount of unreacted water in the reformer increased, and the supplied fuel amount increased due to the direct effect of the combustor load, and this increased the $\mathrm{CO}_{2}$ generation amount sharply, as shown in Figure 12.
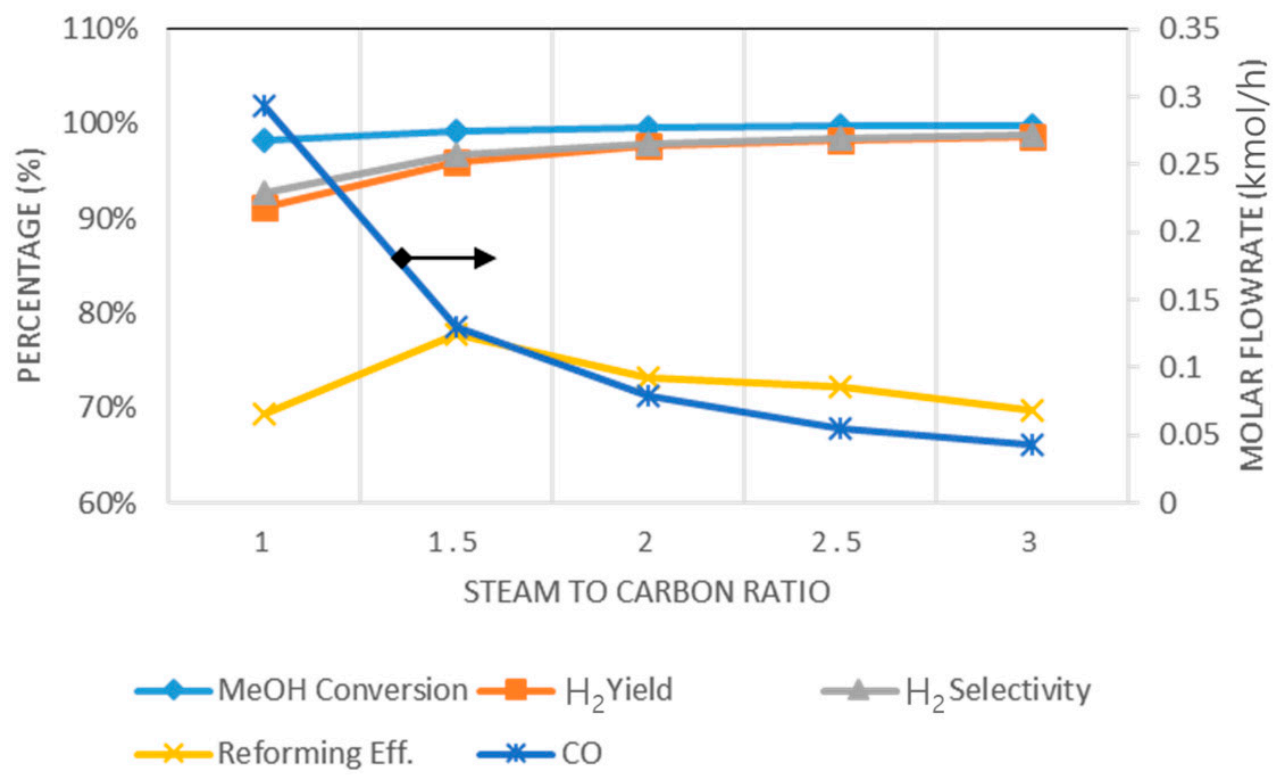

$-\mathrm{H}_{2}$ Selectivity

Figure 11. Effect of steam-to-carbon ratio (SCR) on $\mathrm{MeOH}$ conversion, $\mathrm{H}_{2}$ yield, $\mathrm{H}_{2}$ selectivity, reforming efficiency and $\mathrm{CO}$ flow rate. 


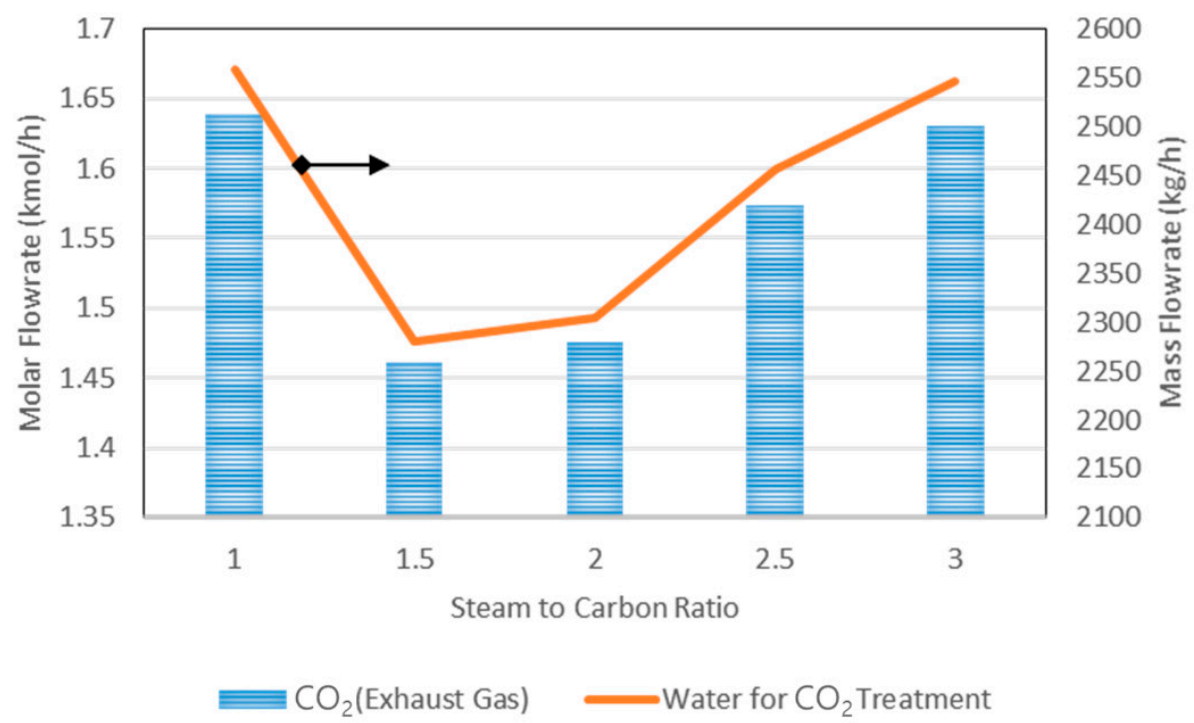

Figure 12. Effect of $\mathrm{SCR}$ on $\mathrm{CO}_{2}$ generated and water to solve $\mathrm{CO}_{2}$.

Figure 13 shows a graph indicating the performance variations for separation efficiencies of $80 \%$, $85 \%, 90 \%$, and $95 \%$ at the reaction temperature of $280{ }^{\circ} \mathrm{C}$, the reaction pressure of $25 \mathrm{bara}$, and the SCR of 1.5. As the separation efficiency increased, methanol conversion ratio, hydrogen yield, and selectivity did not change significantly; however, the reforming efficiency increased. The reason for this is that at low separation efficiency, the amount of fuel supplied to the reformer increases, and thus the amounts of energy and additional fuel required for reforming reaction increase, resulting in a high $\mathrm{CO}_{2}$ generation amount and demand for water to treat it as shown in Figure 14. The separation efficiency varies by the composition of components of the palladium membrane, the reactor design, and fabrication abilities. Therefore, it requires consultation with the manufacturer.

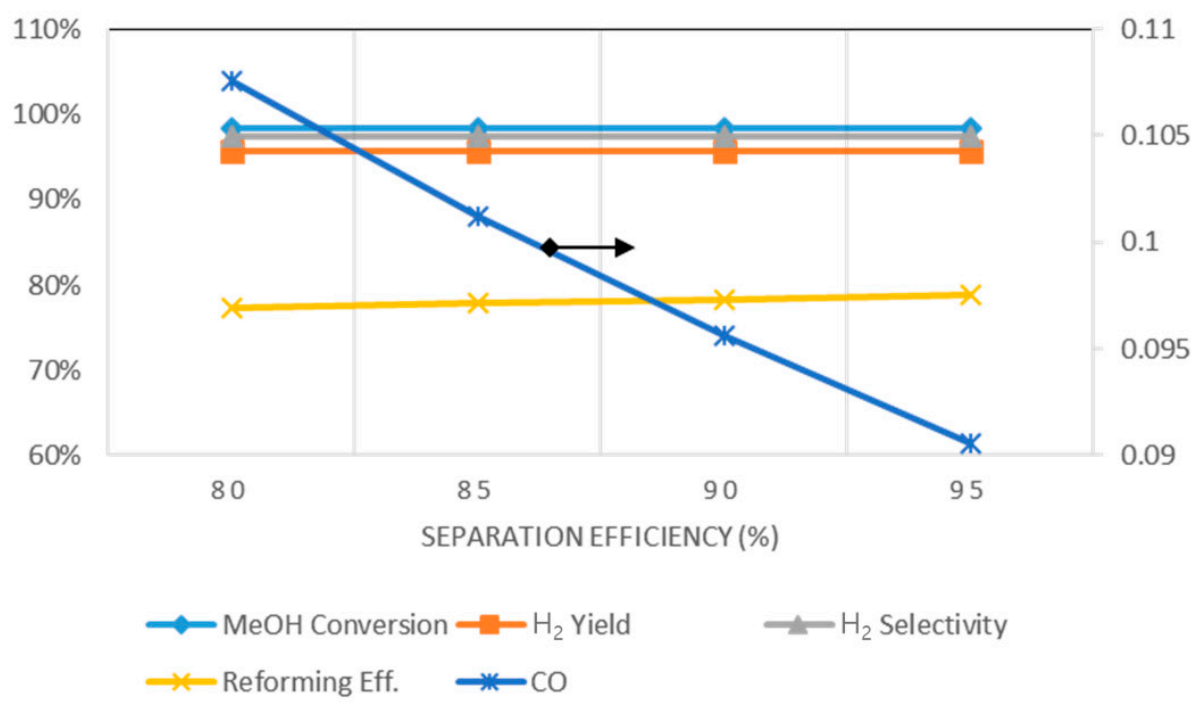

Figure 13. Effect of Separation efficiency on $\mathrm{MeOH}$ conversion, $\mathrm{H}_{2}$ yield, $\mathrm{H}_{2}$ selectivity, reforming efficiency and $\mathrm{CO}$ flow rate. 


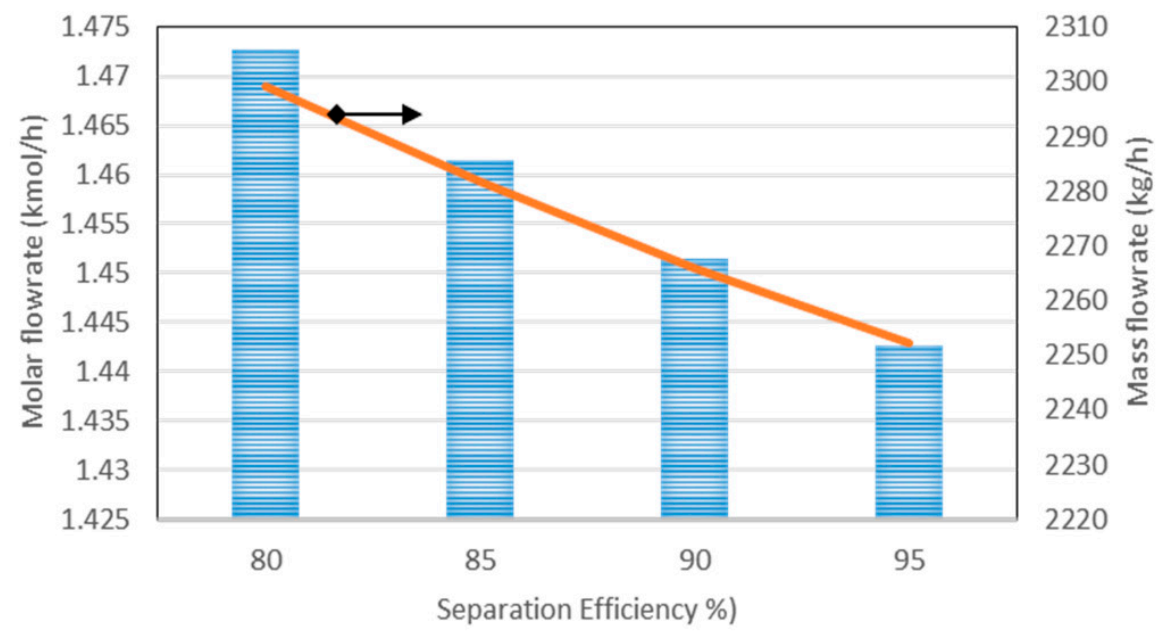

$\equiv \mathrm{CO}_{2}$ (Exhaust Gas) Water for $\mathrm{CO}_{2}$ Treatment

Figure 14. Effect of Separation efficiency on $\mathrm{CO}_{2}$ generated and water to solve $\mathrm{CO}_{2}$.

\section{Conclusions}

In comparison with metal hydride, fuel reforming has excellent storage and placement performances and is considered as a technology that can improve the endurance performance of underwater vehicles equipped with fuel cells. In this study, the optimal fuel in terms of space has been derived, which was methanol, through 0 order analysis using aspen HYSYS for fuels that are expected to be applicable to underwater vehicles, and effect of several variables such as reaction pressure (1.013-30 bara) and temperature $\left(250-300{ }^{\circ} \mathrm{C}\right), \mathrm{SCR}(1-3)$, and separation efficiency $(80 \%-95 \%)$ on the reforming system has been analyzed, and thereby its optimal operation conditions were attained. Based on the conceptual design of a fuel-reforming system for fuel cells in underwater vehicles, the conclusions are summarized as follows:

(1) To produce $1 \mathrm{kmol}$ of hydrogen, $46.3,53.5,51.7$, and $47.6 \mathrm{~kg}$ reactants and oxygen, which is an oxidant, were consumed for methanol, ethanol, gasoline, and diesel, respectively.

(2) Diesel and gasoline had almost the same required spaces, whereas ethanol occupied the largest volume. For methanol, while its storage needed a larger space due to its consumption, the amount of oxygen and compensation water for $\mathrm{CO}_{2}$ was smaller than those of other fuels, the space needed for small. Accordingly, it occupied the smallest volumes.

(3) In the case of methanol, as the reforming pressure increased, the methanol conversion ratio, hydrogen yield and selectivity, and $\mathrm{CO}_{2}$ showed a decreasing tendency. The effect of pressure change on reforming efficiency was low. As the temperature increased, the methanol conversion ratio increased; however, hydrogen selectivity decreased. The reforming efficiency was the highest at $77.7 \%-77.8 \%$ at $260{ }^{\circ} \mathrm{C}$ and $270{ }^{\circ} \mathrm{C}$. An increase in SCR led to an increased hydrogen generation amount, but it facilitated an increase in the amount of additional fuel, $\mathrm{CO}_{2}$ generation, and water storage. At $1.5 \mathrm{SCR}$, the reforming efficiency was the highest at $77.8 \%$, and the $\mathrm{CO}_{2}$ generation amount was the lowest at $1.46 \mathrm{kmol} / \mathrm{h}$.

(4) The separation efficiency did not affect methanol conversion ratio, hydrogen yield, and selectivity. However, under high separation efficiency, the reforming efficiency increased due to the reactant reduction, and the heating value supplied to the reactor also decreased, resulting in a lower $\mathrm{CO}_{2}$ generation amount.

(5) Optimization of a methanol-reforming processor and development of a $\mathrm{CO}_{2}$ dissolution system with minimum volume will be studied in future research. 
Author Contributions: Supervision, S.-K.J. and J.C.; Methodology, S.-K.J., W.-S.C.; Investigation, Y.-I.P., S.-H.K.; Funding acquisition, J.C.; Writing-review \& editing, S.-K.J. and W.-S.C. All authors have read and agree to the published version of the manuscript.

Funding: This research was funded by Defense Acquisition Program Administration.

Acknowledgments: This research is part of the work supported by the Defense Acquisition Program Administration and the Agency for Defense Development. [Project Name: 17-113-407-039].

Conflicts of Interest: The authors declare no conflict of interest.

\section{References}

1. Lee, J.C.; Shay, T. Analysis of fuel cell applied for submarine air independent propulsion (AIP) system. J. Mar. Sci. Technol. 2018, 26, 657-666.

2. Ghosh, P.C.; Vasudeva, U. Analysis of $3000 \mathrm{~T}$ class submarines equipped with polymer electrolyte fuel cells. Energy 2011, 36, 3138-3147. [CrossRef]

3. Psoma, A.; Sattler, G. Fuel cell systems for submarine: from the first idea to serial production. J. Power Sources 2002, 106, 381-383. [CrossRef]

4. Maeda, T.; Ishigura, S. Development of fuel cell AUV URASHIMA, Kitsubishi Heavy Industries, Ltd. Technol. Rev. 2004, 41, 1-5.

5. Mendez, A.; Leo, T.; Herreros, M. Current State of Technology of Fuel Cell Power Systems for Autonomous Underwater Vehicles. Energies 2014, 7, 4676-4693. [CrossRef]

6. Kim, H.D. Concept research of fuel cell system for the UUV. J. Korean Soc. Mar. Environ. Energy 2014, 38, 751-760.

7. Ji, H.J.; Choi, E.Y.; Lee, J.H. Optimal operation condition of pressurized methanol fuel processor for underwater environment. Trans Korean Hydrog. New Energy Soc. 2016, 27, 485-493. [CrossRef]

8. Etienne, R.; Michel, T.; Karim, Z. Hydrogen storage for mobility: A Review. Materials 2019, 12, 1973.

9. Purnima, P.; Jayanti, S. A high-efficiency, auto-thermal system for on-board hydrogen production for low temperature PEM fuel cells using dual reforming of ethanol. Int. J. Hydrogen Energy 2016, 41, 13800-13810. [CrossRef]

10. Ahmed, S.; Krumpelt, M. Hydrogen from hydrocarbon fuels for fuel cells. Int. J. Hydrogen Energy 2001, 26, 291-301. [CrossRef]

11. Chiu, Y.; Chiu, H.; Hsieh, R.; Jang, J.; Jiang, B. Simulations of Hydrogen Production by Methanol Steam Reforming. Energy Procedia 2019, 156, 38-42. [CrossRef]

12. Ming, Q.; Healey, T.; Allen, L.; Irving, P. Steam reforming of hydrocarbon fuels. Catal. Today 2002, 77, 51-64. [CrossRef]

13. Lutz, A.E.; Bradshaw, R.W.; Keller, J.O.; Witmer, D.E. Thermodynamic analysis of hydrogen production by steam reforming. Int. J. Hydrogen Energy 2003, 28, 159-167. [CrossRef]

14. Ni, M.Y.C.; Leung, D.K.H.; Leung, M. A review on reforming bio-ethanol for hydrogen production. Int. J. Hydrogen Energy 2007, 32, 3247. [CrossRef]

15. Danial Doss, E.; Kumar, R.; Ahluwalia, R.K.; Krumpelt, M. Fuel processors for automotive fuel cell systems: a parametric analysis. J. Power Sources 2001, 102, 1-15. [CrossRef]

16. Krumpelt, M.; Krause, T.R.; Cater, J.D.; Kopasz, J.P.; Ahmed, S. Fuel processing for fuel cell systems in transportation and portable power applications. Catal. Today 2002, 77, 316. [CrossRef]

17. Krummrich, S.; Llabres, J. Methanol reformer-The next milestone for fuel cell powered submarines. Int. J. Hydrogen Energy 2015, 40, 5482-5486. [CrossRef]

18. Boon, J.; van Dijk, E.; de Munck, S.; van den Brink, R. Steam reforming of commercial ultra-low sulphur diesel. J. Power Sources 2011, 196, 5928-5935. [CrossRef]

19. Lee, T.J.; Kang, I.Y. Diesel reforming technology for fuel cell system. Ceramist 2012, 15, 11-13.

20. Knapton, A.G. Palladium alloys for hydrogen diffusion membranes. Platin. Metals Rev. 1977, $21,44-50$.

21. Plazaola, A.A.; Tanaka, D.P.; Annaland, M.V.; Gallucci, F. Recent Advances in Pd-Based Membranes for Membrane Reactors. Molecules 2017, 22, 51. [CrossRef] [PubMed]

22. Grashoff, G.J.; Pilkington, C.; Corti, C. The Purification of Hydrogen-A review of the technology emphasizing the current status of palladium membrane diffusion. Johns. Matthey Group Res. Cent. Platin. Metals Rev. 1983, 27, 157-169. 
23. Dickson, A. The carbon dioxide system in seawater: Equilibrium chemistry and measurements. In Guide to Best Practices for Ocean Acidification Research and Data Reporting; North Pacific Marine Science Organization: Sidney, Canada, 2007; pp. 17-40.

24. Zhenhao, D.; Sun, R. An improved model calculating $\mathrm{CO}_{2}$ solubility in pure water and aqueous $\mathrm{NaCl}$ solutions from 273 to $533 \mathrm{~K}$ and from 0 to 2000 bar. Chem. Geol. 2003, 193, 257-271.

25. Kabza, A. Just another Fuel Cell Formulary. Retrieved February 2017. Available online: http://www.pemfc. de/FCF_Smart.pdf (accessed on 17 October 2019).

26. Brighton, D.R.; Mart, P.L.; Clark, G.A.; Rowan, M.J.M. The use of fuel cells to enhance the underwater performance of conventional diesel electric submarines. J. Power Sources 1994, 51, 375-389. [CrossRef]

(C) 2020 by the authors. Licensee MDPI, Basel, Switzerland. This article is an open access article distributed under the terms and conditions of the Creative Commons Attribution (CC BY) license (http://creativecommons.org/licenses/by/4.0/). 